



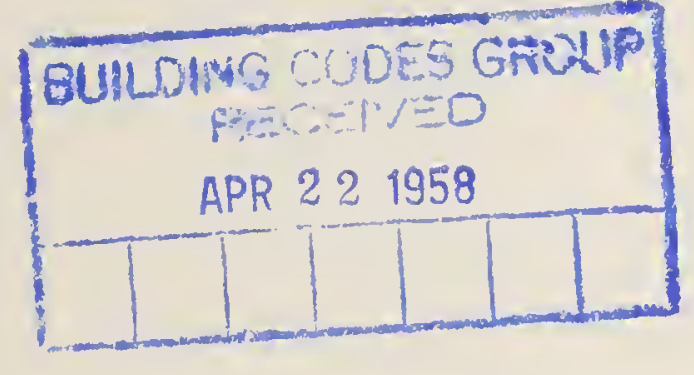







\section{Fire Resistance of Concrete Floors}

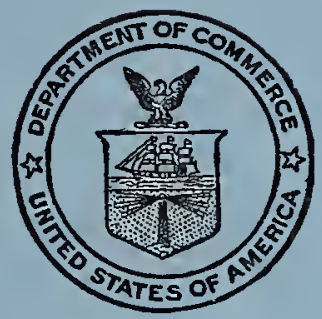

United States Department of Commerce National Bureau of Standards Building Materials and Structures Report 134 


\section{BUILDING MATERIALS AND STRUCTURES REPORTS}

On request, the Superintendent of Documents, U. S. Government Printing Office, Washington $25, \mathrm{D}$. C., will place your name on a special mailing list to receive notices of new reports in this series as soon as they are issued. There will be no charge for receiving such notices.

If 100 copies or more of any report are ordered at one time, a discount of 25 percent is allowed. Send all orders and remittances to the Superintendent of Documents, U. S. Government Printing Office, Washinglon $25, D$. C.

The following publications in this series are available by purchase from the Superintendent of Documents at the prices indicated:

BMS2 Methods of Determining the Structural Properties of Low-Cost House Constructions_ _ $10 \&$

BMS3 Suitability of Fiber Insulating Lath as a Plaster Base

BMS4 Accelerated Aging of Fiber Building Boards _.

BMS5 Structural Properties of Six Masonry Wall Constructions

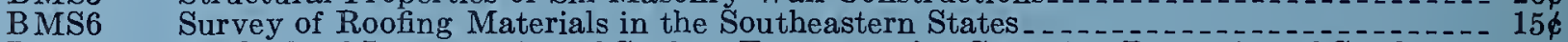

BMS8 Methods of Investigation of Surface Treatment for Corrosion Protection of Steel

BMS9 Structural Properties of the Insulated Steel Construction Co.'s "Frameless-Steel" Constructions for Walls, Partitions, Floors, and Roofs _...

BMS10 Structural Properties of One of the "Keystone Beam Steel Floor" Constructions Sponsored by the H. H. Robertson Co ...

BMS11 Structural Properties of the Curren Fabrihome Corporation's "Fabrihome" Constructions for Walls and Partitions

BMS12 Structural Properties of "Steelox" Constructions for Walls, Partitions, Floors, and Roofs Sponsored by Steel Buildings, Inc._._.

BMS14 Indentation and Recovery of Low-Cost Floor Coverings

BMS15 Structural Properties of "Wheeling Long-Span Steel Floor" Construction Sponsored by the Wheeling Corrugating Co _....... 10 \&

BMS16 Structural Properties of a "Tilecrete" Floor Construction Sponsored by Tilecrete Floors, Ine. -

BMS17 Sound Insulation of Wall and Floor Constructions

Supplement to BMS17, Sound Insulation of Wall and Floor Constructions

Supplement No. 2 to BMS17, Sound Insulation of Wall and Floor Constructions

BMS18 Structural Properties of "Pre-fab" Constructions for Walls, Partitions, and Floors Sponsored by the Harnischfeger Corporation

BMS20 Structural Properties of "Twachtman" Constructions for Walls and Floors Sponsored by Connecticut Pre-Cast Buildings Corporation -........... $10 \notin$

BMS21 Structural Properties of a Concrete-Block Cavity-Wall Construction Sponsored by the National Concrete Masonry Association

BMS23 Structural Properties of a Brick Cavity-Wall Construction Sponsored by the Brick Manufacturers Association of New York, Inc -

BMS24 Structural Properties of a Reinforced-Brick Wall Construction and a Brick-Tile Cavity-Wall Construction Sponsored by the Structural Clay Products Institute _. $15 \phi$

BMS25 Structural Properties of Conventional Wood-Frame Constructions for Walls, Parti-

BMS26 Structural Properties of "Nelson Pre-Cast Concrete Foundation" Wall Construction Sponsored by the Nelson Cement Stone Co., Inc _........... 10

BMS27 Structural Properties of "Bender Steel Home" Wall Construction Sponsored by the Bender Body $\mathrm{Co}_{-}$

BMS28 Backflow Prevention in Over-Rim Water Supplies

BMS29 Survey of Roofing Materials in the Northeastern States....

BMS30 Structural Properties of a Wood-Frame Wall Construction Sponsored by the Douglas Fir Plywood Association.

BMS32 Structural Properties of Two Brick-Concrete-Block Wall Constructions and a Concrete-Block Wall Construction Sponsored by the National Concrete Masonry Association .........

[List continued on cover page 111] 
Errata to accompany National Bureau of Stardards Builaing Materials and Structures Report Birs 134. "Fire Resistance of Concrete Floors."

Page 4, right colurn, section 4.6́. Formula (I) should read:

$$
t_{f}=\beta \rho L^{2.7} 10^{-\frac{b}{2}}
$$

Page 5, the sentence inmediately above table 2 should read:

The difference between the $\beta$ values for siliceousand calcareous-aggregate concretes was considered to be real and may be attributed. to endothermic changes that take place in calcareous-aggregate concretes when heated, which would tend to increase the fire endurance. 



\title{
Fire Resistance of Concrete Floors
}

\author{
Daniel S. Goalwin
}

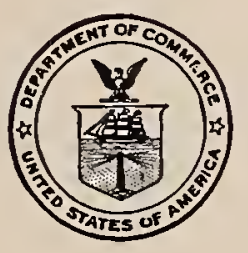

Building Materials and Structures Report 134

Issued December, 261952 


\section{Foreword}

This report is one of a series issued by the National Bureau of Standards dealing with the fire resistance of building materials and constructions. It indicates the results in a series of tests of concrete floors.

The information is intended to aid building authorities and regulatory groups in evaluating the fire-resistance characteristics of concrete floor constructions and to give designers and builders a basis for the selection of constructions that will meet given requirements with respect to fire resistance.

A. V. Astin, Director.

\section{Contents}

Foreword .

1. Introduction

2. Test methods

3. Test results

4. Discussion $\ldots \ldots \ldots \ldots \ldots \ldots$

4.1. Type of aggregate $\ldots \ldots \ldots \ldots \ldots \ldots$

4.2. Effect of restraining forces

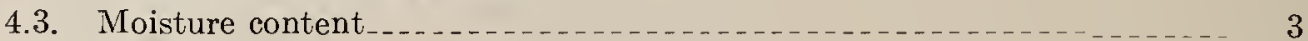

4.4. Soffit protection

4.5. Joists

4.6. Effect of slab thickness and density

4.7. General $\ldots$

5. References 


\title{
Fire Resistance of Concrete Floors
}

\author{
Daniel S. Goalwin
}

\begin{abstract}
The results of eleven exploratory and four full-scale fire-endurance tests on reinforced concrete floors are given. All the slabs were monolithic and were made with gravel aggregates; six consisted of slabs cast to engage the tops of precast lightweight concrete joists. The effects of moisture content, aggregate type, and soffit protection are discussed. A general equation for the relation between slab thickness and fire resistance for different aggregates is proposed.
\end{abstract}

\section{Introduction}

The increasing use of concrete slab floors in industrial and commercial building and multiple residential dwellings emphasizes the need for adequate fire-resistance ratings of these components. The proper selection of fire-resistant floor material, together with a closure of vertical openings, can restrict fires in large buildings to one floor for a considerable length of time, allowing proper abatement measures to be taken in the rest of the building.

This report covers the result of 11 exploratory fire-endurance tests and 4 full-scale tests on monolithic concrete floors made with siliceousgravel aggregates. It includes a series of tests on reinforced slabs of 4 - to 8-in. thickness tested to determine the relationship between floor thickness and fire resistance, as well as on a series of six $21 / 2-$ and 3 -in.-thick floors tested primarily to investigate the fire resistance of concrete floors made with prefabricated concrete joists. Several of the tests were made to determine the fire-endurance limits of a particular construction without regard to other constructions; therefore, some of the data are lacking that are essential to an over-all evaluation of the relationships between the fire endurance and such variables as the slab thickness, type of aggregate; strength and density of the concrete, and method and time of curing the concrete. The specific results presented should be of interest to laboratory workers, designers, builders, and the writers and administrators of building codes.

\section{Test Methods}

The full-scale tests were made in accordance with the American Society for Testing Materials Specification E119-47, and the American Standards Association Standard Specifications for Fire Tests of Building Construction and Materials, No. A21-1942, which require that a fire exposure with standard time-temperature relation shall be applied to the under sicle of a test floor having no dimension less than $12 \mathrm{ft}$ and an area of at least $180 \mathrm{sq} \mathrm{ft}$. The specifications require that the floor must carry a continuously applied load sufficient to cause the maximum allowable working stress in the structural members. The criterion of failure may be either (a) structural (load failure), (b) the passage of direct flame or hot gases through the floor, or (c) a rise of the average temperature on the upper surface of the floor of $250^{\circ} \mathrm{F}$ or of the temperature at a single point on the upper surface of $325^{\circ} \mathrm{F}$.

An average temperature rise of $1,000 \operatorname{deg} \mathrm{F}$ on the reinforcing steel or of $1.200 \mathrm{deg} F$ at a single point on the reinforcing steel is considered critical in these tests, inasmuch as the yield strength of carbon steel at $1,000^{\circ} \mathrm{F}$ is only about half its value at $70^{\circ} \mathrm{F}$, and it decreases even more markedly as the temperature rises above $1,000^{\circ} \mathrm{F}$. The standard fire-exposure temperatures specified are sliown in the various curves of test results, together with the actual temperatures achieved. While the tests of the small floors, those suffixed with the letter $\mathrm{A}$, may be considered exploratory, every effort was made to use the standard time-temperature curre. Loadings were in accordance with the ASA test specifications except for floors $70 \mathrm{~A}, 71 \mathrm{~A}$, and $72 \mathrm{~A}$, which were tested primarily to study the effects of moisture content and were tested without load.

The floors were tested in gas furnaces. 'The furnace temperatures were achieved by means of gas burmers in the furnace below the test floor. Temperature measurements were obtained with 12 chromel-alumel thermocouples in the large furnace and 6 in the small furnace, symmetrically arrauged and encased in iron protection tubes. The temperature of the upper surface of the floors was measured by means of thermocouples placed on top of the floor and protected against radiation and convection effects by 6- by 6-in. dry feltedasbestos pads 0.4 in. thick. In some of the tests thermocouples were also embedded at rarious points within the floor construction.

The loads on the floors were selected to cause the maximum allowable stress in the test members and varied from about 40 to $80 \mathrm{lb} / \mathrm{ft}^{2}$.

The floor deflections were measured during the tests to obtain a quantitative measure of load failure or an indication of approaching load failure. Deflection measurements when made were by means of reighted wires rumning over a pulley system to the outside of the test structure, where pointers were read against graduated scales.

Curing of the floors was in two stages: during the first stage, the floors were corered with burlap and kept wetted; during the second stage, the floors were heated from underneatl, the furnace temperature varying in different tests from $100^{\circ}$ 
TABLE 1. Summary of fire-endurance tests of reinforced-concrete floor eonstruetions ${ }^{1}$

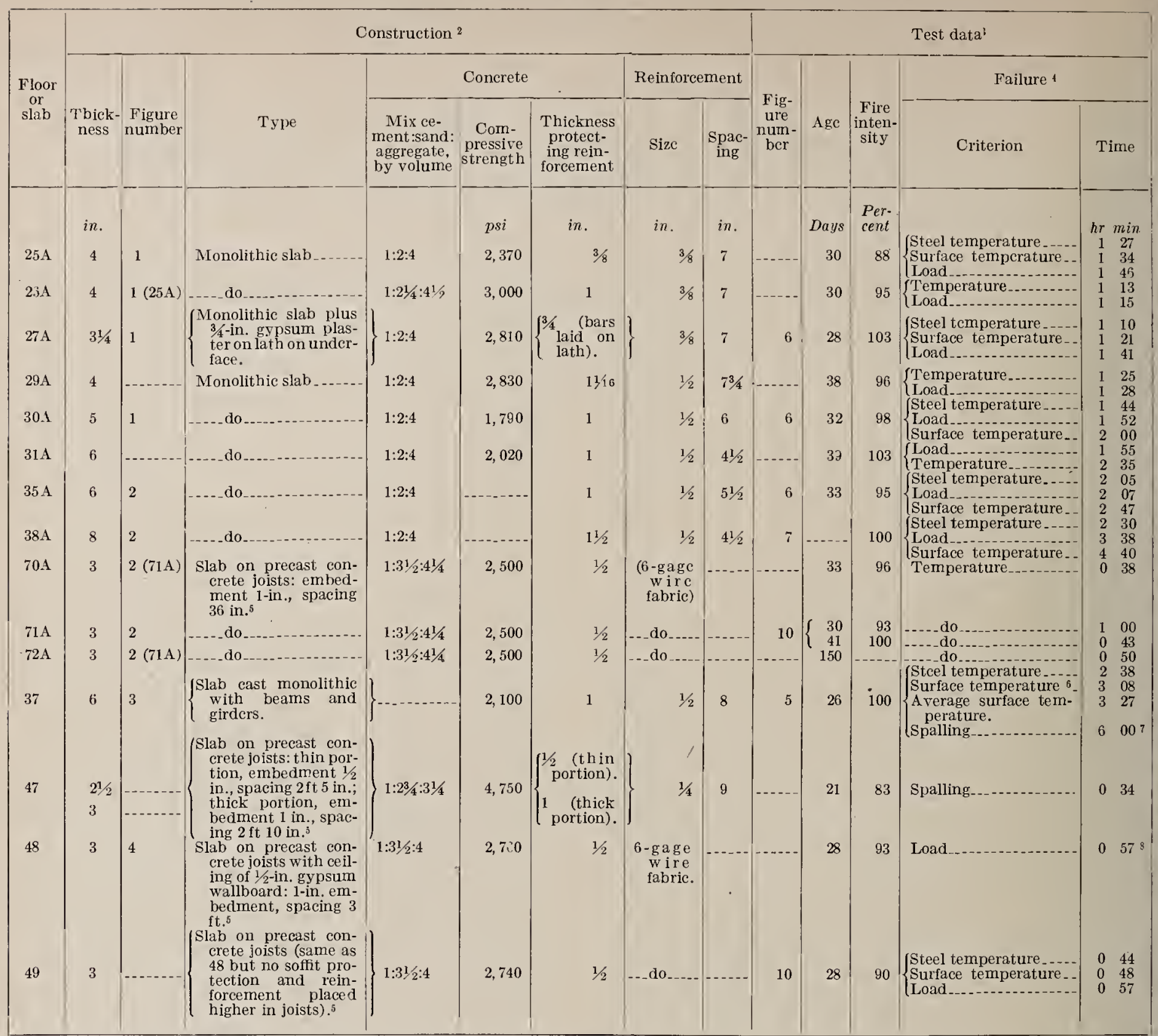

I Floors $37,47,48$, and 49 were $13 \frac{1}{2} / 2$ by $17 \mathrm{ft}$ in horizontal area; all the others were $41 / 2$ by $9 \mathrm{ft}$.

2 All slabs were of gravel aggregatc. Potomac River gravel mineral content: vein quartz $21 \%$, quartzite $38 \%$, sandstone $23 \%$, cbert $12 \%$. Potomac River sand mineral content: vein quartz $90 \%$, mica $4 \%$.

3 All floors, cxcept $70 \mathrm{~A}, 71 \mathrm{~A}$, and $72 \mathrm{~A}$, were loaded to 20,000 -psi nominal stress. These three were not loaded.

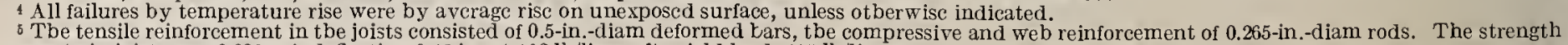
of concretc in joists was $2,230 \mathrm{psi}$; deflection $0.42 \mathrm{in}$. at $162 \mathrm{lb} / \mathrm{linear} \mathrm{ft}$; yield load, $415 \mathrm{lb} / \mathrm{linear} \mathrm{ft}$.

6 At one point only.

7 No failure of beams at $6.0 \mathrm{hr}$.

8 Temperature risc limit not reached at 1 br $10 \mathrm{~min}$.

to almost $250^{\circ} \mathrm{F}$. The total curing time ranged from 21 to 41 days, with one exception.

The monolithic constructions were made with siliceous aggregates from $1 / 2$ to $11 / 4$ in. maximum size. Proportions of the mixes are given in table 1.

The full-scale floors, $37,47,48$, and 49 , were about $131 / 2 \mathrm{ft}$ wide by $17 \mathrm{ft}$ long. Smaller floors about $41 / 2 \mathrm{ft}$ wide by $9 \mathrm{ft}$ long were also tested to provide data on other variables. Construction details of some of the floors are shown in figures 1 , 2,3 , and 4; loading data and details of the mixes and curing are tabulated in table 1 .

\section{Test Results}

The compressive strengths of control cylinder's were measured at the end of the curing period for each of the floor slabs; the data are given in table 1. Compressive strengths of the prefabricated joists used in floors 47 through 49 and $70 \mathrm{~A}$ through $72 \mathrm{~A}$ are also given in table 1 . Timetemperature curves for some of the slabs are given in figures $5,6,7$, and 10 . Each of the graphs shows the standard, maximum, and average furnace temperatures, the average and maximum 
temperatures of the slab top, and, in some cases, the average and maximum temperatures in the principal reinforcement. Figures 8, 9, 11, and 12 show the condition of some of the specimens before and after test. The fire intensity, defined as the ratio of actual temperatures to standard temperatures integrated over the period of the test, is also given in table 1.

\section{Discussion}

\subsection{Type of Aggregate}

Deflection of a slab due to differential thermal expansion in the material takes place in the direction of the heated surface and is, with certain simplifying assumptions, proportional to the temperature gradient through the slab, the square of a linear slab dimension, and the coefficient of thermal expansion [1]. As concretes made with limestone or blast-furnace slag (calcareous aggregates) in general have lower coefficients of thermal expansion than do concretes made with gravel or quartz (siliceous) aggregates $[2,3,4]$ smaller deflections may in general be expected for slabs of the former than for the latter. Menzel's data [5] on concrete walls give qualitative confirmation.

In addition, the temperature rise within siliceous-aggregate concrete slabs will be greater than for calcareous-aggregate concrete slabs under similar test conditions due to the higher thermal conductivity $[6,7]$. Data on the thermal conductivities of concretes are scarce, but, as with most solid materials, such conductivities are found to increase with temperature. For clay brick, for instance, the thermal conductivity doubles between $100^{\circ}$ and $2,000^{\circ} \mathrm{F}$.

Chemical changes also take place as the concrete is heated. Large volume changes take place as a lesult of chemical action in chert and quartz at relatively low temperatures; these tend to aggravate strains due to differential expansion in the structure. Chemical changes in concretes made of calcareous aggregates are endothermic, thus tending to retard temperature rise in the structure.

Entrapment of water or water vapor in the more impervious concretes may have a deleterious effect on their fire resistance. While the moisture has a high heat capacity and consequently retards the temperature rise, the pressures developed on heating and the resultant expansion of the water cause additional strains in the structure and may cause flaking or spalling. This effect has been observed not only with quartz and chert gravel aggregates but also with high-strength concretes in which the aggregates were limestone or crushed firebrick [8].

The tests reported herein were made only on concretes of siliceous aggregates, and, with one exception, Potomac River gravel of $1 / 2$ - to $3 / 4$-in. size was used. The fire resistance on corresponding

1 Numbers in brackets indicate the literature references at the end of this report. units made of calcareous or high-grade cinder aggregate concretes may be assumed to be higher $[9,5]$.

There is some evidence that the fire endurance of concrete containing siliceous aggregate alone increases slightly as the strength or impermeability of the concrete decreases. The data are not sufficient to draw quantitative conclusions. However, it is interesting to note that for the series of 4-in.-thick slabs of similar construction and aging, the failure by temperature rise varied from $1.22 \mathrm{hr}$ with 3,000-psi concrete to $1.57 \mathrm{hr}$ with 2,375 -psi concrete, and the time of load failure varied from $1.25 \mathrm{hr}$ with the $3,000-\mathrm{psi}$ concrete to $1.77 \mathrm{hr}$ for the 2,375-psi concrete.

\subsection{Effect of Restraining Forces}

Load failure of concrete slabs subjected to the fire test may be influenced by the type of restraint against lateral expansion. If the floor is restrained at the edges, the resulting stresses will accelerate spalling; in an unrestrained floor, the only expansion stresses are those due to thermal gradients in the slab. The large slabs of this series may be considered to be partially restrained because of light framing at the edges and the lower temperatures toward the edges of the slab. The $41 / 2^{-}$by 9 -ft floors tested in the small furnace may be considered to have been entirely unrestrained except for the negligible bearing friction at the ends and the temperature gradient toward the edges. Ingberg [1] discusses the effect of restraint on fire endurance in some detail.

\subsection{Moisture Content}

For most of the tests of this series, data on moisture content of the concrete at the time of test are not available. A relationship may be expected to exist between moisture content of the concrete and the fire endurance, higher moisture content at the start of the fire exposure resulting in greater resistance to the fire. In the case of some dense concretes, however, excess moisture content may result in spalling as pressure is built up within the concrete.

As the method of curing was fairly similar for all the slabs tested, the indications are that the differences in fire resistance were probably not due entirely to the variation in moisture content of the slabs. The control slab of one of the floors, cured in a manner typical of the entire group of floors, decreased in weight by 3.1 percent in a drying period of 21 days, during 14 of which it was being heated. Another control slab showed a residual moisture content of 4 percent at the time of the test.

Most of the floors were aged for 30 days and, while they were oven-heated for part of this time, they may not have been as dry as construction that had been in place for several years; it is generally 
considered that a concrete slab in place in a heated building will lose most of its free moisture in from 1.5 to 2 years. In this respect, it may be interesting to compare the results of tests made on floors of identical construction, $70 \mathrm{~A}$ and $71 \mathrm{~A}$. Floor $70 \mathrm{~A}$, which had been heated at $100^{\circ} \mathrm{F}$ for 1 week and at $150^{\circ} \mathrm{F}$ for an additional week, took $38 \mathrm{~min}$ to reach the limiting temperature on the upper surface at an age of 28 days. Floor $71 \mathrm{~A}$, which was not oven-heated, took $60 \mathrm{~min}$ at an age of 39 days to reach the same limiting temperature. Floor $71 \Lambda$ was retested 11 days after the first test, at which time it may be considered to have been representative of a condition of extreme dryness. In the retest, the limiting temperature was reached in $43 \mathrm{~min}$.

Menzel's data [5] on concrete wall slabs includes a retest of each slab after the initial nonload-bearing fire test. The reductions in time to reach limiting temperature in the retest as compared to the original test ranged from 7 to 48 percent. Menzel's floors had been cured for 1 year without anxiliary heating before the first tests.

\subsection{Soffit Protection}

The data in this series of tests are, with one or two exceptions, for floors without plaster. It is recognized, of course, that the addition of a prop. erly designed ceiling below a floor can increase the fire resistance of a reinforced concrete slab.

In floor 48 , the joists were protected by a ceiling of $1 / 2$-in. gypsum wallboard that had been painted with one coat of cold-water paint. Parts of the wallboard began to fall after $15 \mathrm{~min}$ of exposure to fire, and the entire wallboard had fallen by 30 min. The duration of the applied fire was $1 \mathrm{hr}$ $10 \mathrm{~min}$, at which time the temperature limit had not been reached, the floor having failed under load. Floor 49, consisting of a slab similar to that of floor 48 but without soffit protection, failed by temperature rise at 48 min. The ceiling thus gave at least $20 \mathrm{~min}$ of additional fire protection to the slab.

Floor $27 \mathrm{~A}$ was protected by $3 / 4$-in. gypsum plaster on lath on the underface of the slab. This $31 / 4$-in. slab failed by temperature rise at $1 \mathrm{hr} 21$ min as compared to an average failure time of $1 \mathrm{hr}$ $30 \mathrm{~min}$ for three 4 -in. slabs of the same general construction but with no plaster protection. Load failure occurred at $1 \mathrm{hr} 54 \mathrm{~min}$ compared with an average of $1 \mathrm{hr} 30 \mathrm{~min}$ for the 4 -in.-thick floors.

Other tests have shown more conclusively the effectiveness of plaster as a fire retardant whether applied on metal lath or directly to the concrete. The Canadian code, for instance, allows a reduction of up to $1 \mathrm{in}$. in slab thickness if a ceiling of $3 / 4$-in. gypsum plaster is used.

\subsection{Joists}

The precast joists of floors $47,48,49,70 \mathrm{~A}, 71 \mathrm{~A}$, and $72 \Lambda$ (figs. 2 and 4 , and table 1 , footnote 5 ) contained haydite, a burned-clay aggregate (lightweight). The performance of the unprotected joists of floor 47 could not be determined because of early failure of the slab by spalling. In the cases of both floors 47 and 48 , the bond between the joists and the slab was found to be broken. The encasement of the upper part of the joists in the slab was 0.5 to $1.0 \mathrm{in}$.

'To prevent bond failure in floor 49 , the $1 / 4$-in. compression bars were moved $1 \mathrm{in}$. upward so as to be adjacent to and just inside the top of the joist, and the joists were embedded 1 in. into the slab; the joist web rods thus served as reinforcement against shear of the joists at the level of the bottom of the slab. This also gave additional concrete protection below the steel of the joists. The tension steel in this floor reached $1,000^{\circ} \mathrm{F}$ in 44 min, the upper surface of the floor reached limiting temperature in $48 \mathrm{~min}$, and the floor failed under load at $57 \mathrm{~min}$. 'The joists spalled only slightly, and the bond between the joists and floor did not fail. The unprotected joists thus have a fire endurance of approximately $3 / 4 \mathrm{hr}$, the loadcarrying ability of the joists under fire being dependent upon the thickness of the concrete protecting the steel.

\subsection{Effect of Slab Thickness and Density}

The fire endurance of a concrete slab, as determined by temperature rise only, is plotted in figure 13 against the slab thickness. Although the scatter of the points is large, the fire endurance may be best represented as varying with the 1.7 power of the slab thickness. This relation of thickness to fire resistance is also given in BMS92 $[10]^{2}$ for other types of construction.

An empirical relation las been developed giving the time for failure of a concrete slab due to 250 deg F temperature rise as a function of the density of the concrete and the thickness of the slab. This formula is

$$
t_{f}=\beta \rho L^{1 . \tau} 10-\frac{\rho}{2}
$$

where $t_{f}$ is the time to failure by $250 \mathrm{deg} \mathbf{F}$ temperature rise, $I$ is the slab thickness, $\rho$ is the specific gravity of the concrete (water $=1$ ), and $\beta$ is a proportionality constant.

The validity of equation 1 for predicting the results of fire-endurance tests has been evaluated by calculating $\beta$ for fire tests conducted at the National Bureau of Standards and in the Portland

\footnotetext{
2 The thermal conductivity of concrete is obtainable from data given in reference [7] and inpublislied NBS data as

$$
k=a \cdot 10^{\circ},
$$

where $k$ is the thermal conductivity, $a$ is the constant, $p$ is the specific gravity of the concrete.
} 
Cement Association Laboratories in Chicago [5] on 28 concrete slabs of various aggregates and thicknesses. Some of the slabs were tested vertically, some horizontally. The data and calculated values are listed in table 2 . In this table $t_{f}$ is in hours, $\rho$ is dimensionless (specific gravity), $L$ is in inches, and $\beta$ is a constant of mixed units that includes specific heat and the heat-transfer coefficient.

The average value of $\beta$ for siliceous-aggregate concrete slabs was found to be 0.74 ; for slabs of calcareous aggregates, 0.96 ; for haydite, 1.00 ; and for a mixture of siliceous and haydite aggregates, 0.87 . The difference between the $\beta$ values for siliceous- and calcareous-aggregate concretes was considered to be real and may be attributed to exo-

TABLE 2. Validity of generalized fire-resistance formula

\begin{tabular}{|c|c|c|c|c|c|c|}
\hline $\begin{array}{l}\text { Aggre- } \\
\text { gate 1 }\end{array}$ & $\begin{array}{l}\text { Source } \\
\text { of data }{ }^{2}\end{array}$ & $\begin{array}{l}\text { Thick- } \\
\text { ness, } L\end{array}$ & $\begin{array}{c}\text { Specific } \\
\text { gravity } \\
\rho \\
\rho\end{array}$ & $\begin{array}{l}\text { Time to } \\
\text { failure, } t \text { s }\end{array}$ & $\begin{array}{c}\text { Propor- } \\
\text { tionality } \\
\text { con- } \\
\text { stant, } \beta\end{array}$ & $\begin{array}{l}\text { Devia- } \\
\text { tion } \\
\text { from } \\
\text { average }\end{array}$ \\
\hline 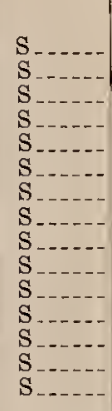 & $\begin{array}{c}\text { M } \\
\text { M } \\
\text { M } \\
\text { NBS } \\
\text { NBS } \\
\text { NBS } \\
\text { NBS } \\
\text { NBS } \\
\text { NBS } \\
\text { NBS } \\
\text { M } \\
\text { M } \\
\text { M } \\
\text { NBS } \\
\text { NBS }\end{array}$ & $\begin{array}{c}i n . \\
4 \\
6 \\
8 \\
4 \\
4 \\
4 \\
5 \\
6 \\
6 \\
8 \\
6 \\
6 \\
6 \\
3 \\
3\end{array}$ & $\begin{array}{l}2.26 \\
2.24 \\
2.20 \\
2.2 \\
2.2 \\
2.2 \\
2.2 \\
2.2 \\
2.2 \\
2.2 \\
2.25 \\
2.24 \\
2.26 \\
2.2 \\
2.2\end{array}$ & $\begin{array}{c}h r \\
1.10 \\
2.50 \\
4.55 \\
1.28 \\
1.35 \\
1.42 \\
2.00 \\
2.58 \\
2.82 \\
4.67 \\
2.63 \\
2.50 \\
2.38 \\
1.00 \\
0.83\end{array}$ & $\begin{array}{l}0.65 \\
.72 \\
.75 \\
.72 \\
.76 \\
.80 \\
.76 \\
.70 \\
.76 \\
.78 \\
.75 \\
.70 \\
.68 \\
.82 \\
.70\end{array}$ & $\begin{array}{l}0.09 \\
.02 \\
.01 \\
.02 \\
.02 \\
.06 \\
.02 \\
.04 \\
.02 \\
.04 \\
.01 \\
.04 \\
.06 \\
.08 \\
.04\end{array}$ \\
\hline \multicolumn{2}{|c|}{ A verage } & $\ldots$ & 1 & & 0.74 & 0.04 \\
\hline 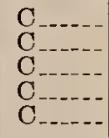 & $\begin{array}{l}\mathrm{M} \\
\mathrm{M} \\
\mathrm{M} \\
\mathrm{M} \\
\mathrm{M}\end{array}$ & $\begin{array}{l}4 \\
6 \\
8 \\
6 \\
6\end{array}$ & $\begin{array}{l}2.35 \\
2.37 \\
2.35 \\
2.45 \\
2.40\end{array}$ & $\begin{array}{l}1.37 \\
3.27 \\
5.52 \\
3.02 \\
3.27\end{array}$ & $\begin{array}{r}0.82 \\
.98 \\
1.00 \\
.98 \\
1.00\end{array}$ & $\begin{array}{r}0.14 \\
.02 \\
.04 \\
.02 \\
.04\end{array}$ \\
\hline \multicolumn{2}{|c|}{ A verage } & 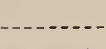 & & & 0.96 & 0.05 \\
\hline $\begin{array}{l}\mathrm{H} \\
\mathrm{H} \\
\mathrm{H} \\
\mathrm{H} \\
\mathrm{H}\end{array}$ & $\begin{array}{l}\mathrm{M} \\
\mathrm{M} \\
\mathrm{M} \\
\mathrm{M} \\
\mathrm{M}\end{array}$ & $\begin{array}{l}4 \\
6 \\
8 \\
6 \\
6\end{array}$ & $\begin{array}{l}1.39 \\
1.38 \\
1.47 \\
1.46 \\
1.38\end{array}$ & $\begin{array}{c}2.33 \\
6.38 \\
10.0 \\
8.12 \\
6.38\end{array}$ & $\begin{array}{l}0.82 \\
1.02 \\
1.02 \\
1.09 \\
1.02\end{array}$ & $\begin{array}{l}0.17 \\
.02 \\
.02 \\
.09 \\
.02\end{array}$ \\
\hline \multicolumn{2}{|c|}{ A verage } & & & & 1.00 & 0.07 \\
\hline $\begin{array}{l}\text { SH } \\
\text { SH....-. } \\
\text { SH.... }\end{array}$ & $\begin{array}{l}\mathrm{M} \\
\mathrm{M} \\
\mathrm{M}\end{array}$ & $\begin{array}{l}6 \\
6 \\
6\end{array}$ & $\begin{array}{l}1.80 \\
1.88 \\
1.84\end{array}$ & $\begin{array}{l}\text { 3. } 98 \\
\text { 4. } 20 \\
4.23\end{array}$ & $\begin{array}{r}0.83 \\
.89 \\
.88\end{array}$ & $\begin{array}{r}0.04 \\
.02 \\
.01\end{array}$ \\
\hline & & & & & 0.87 & 0.02 \\
\hline
\end{tabular}

${ }_{1} \mathrm{~S}=$ siliceous; $\mathrm{C}=$ calcareous; $\mathrm{H}=$ haydite; $\mathrm{SH}=$ equal quantities siliceous and haydite aggregates.

${ }^{2} \mathrm{M}=$ Menzel (slabs tested vertically); NBS=National Bureau of Standards (slabs tested horizontally).

${ }_{3}^{3}$ Specific gravity $(\rho)$ values for the NBS slabs are average values based upon measurements of representative slabs.

${ }_{4} \beta=\frac{t \rho}{\rho} L^{-1.7} 10$. thermic changes that take place in siliceous-aggregate concretes when heated, which would tend to decrease the fire endurance. It may be noted that the specific gravities of the siliceous- and calcareous-aggregate concretes were very similar.

The above $\beta$ values were obtained from data on typical medium-dry slabs. In accordance with data obtained by retesting slabs after the initial fire tests, the "bone-dry" condition may be reasonably represented by a decrease in fire endurance of from 10 to 35 percent. Very wet slabs may be expected to have fire endurances not exceeding 30 percent greater than those calculated from equation 1.

\subsection{General}

In all the tests described in this report, the fire was applied to the underside of the floor in accordance with ASA specifications for fire tests. It is to be expected that fire conditions on the upper side of the floor will not be as severe as on the bottom of the slab because of convection effects, and that the fire endurance of concrete floors will be as great or greater when exposed to fire from the top as when exposed from the bottom.

The effect of reinforcement has not been investigated thoroughly. It is apparent that if the protection for the reinforcing bars is not adequate, the temperature rise in the bars may be such as to cause failure due to decrease in yield strength, even though the temperature on top of the floor has not risen the necessary amount to cause failure by temperature rise. (The yield strength of carbon steel drops rapidly as the temperature approaches $1,000^{\circ} \mathrm{F}$.) Menzel [5] presents some interesting data on the temperatures within the slab, indicating the concrete covering required under the reinforcement for a given protection for the steel. For siliceous sand and gravel, a concrete covering of 1 in. under the reinforcement in a 6 -in. slab keeps the steel temperature below $1,000^{\circ} \mathrm{F}$ for $11 / 2$ hours.

The results of tests of essentially identical floor's were found to differ considerably, due in part to uncontrolled or unreproducible variables, such as differences in the moisture content, workmanship, size of aggregates, density of concrete, and details of curing and framing. The tests provide qualitative information as to the ranges of fire endurance to be expected and the character of failure to be encountered.

Acknowledgement is made to the various manufacturers who supplied materials and assisted in the erection of some of the full-scale floors, to $\mathrm{S}$. H. Ingberg, N. D. Mitchell, H. D. Foster, and other members of the Fire Protection Section who planned, supervised, and conducted the tests. 


\section{References}

[1] S. H. Ingberg, Size and border conditions of test specimens in their relation to results of fire tests, Proc. ASTM 49, 1065 (1949).

[2] W. H. Johnson and W. H. Parsons, Thermal expansion of concrete aggregate materials, J. Research NBS 32, 101 (1944), RP1578.

[3] D. G. R. Bonnell and F. C. Harper, The thermal expansion of concrete, British National Building Studies, Technical Paper No. 7, DSIR (Building Research Station) (1951).

[4] P. H. Peterson, Burned shale and expanded clay concretes, J. Am. Concrete Inst. 20, 165 (1918).

[5] C. A. Menzel, Tests of the fire resistance and thermal properties of solid concrete slabs and their significance, Proc. ASTM 43, 1099 (1943).

[6] R. IV. Kluge, M. M. Sparks, and E. C. Tuma, Lightweight-aggregate concrete, Proc. Am. Concrete Inst. 40, 625 (1949).

[7] Lightweiglit aggregate concretes, U. S. Housing and Home Finance Agency (1949).
[8] Nolan D. Mitchell, Fire tests of steel columns protected with siliceous aggregate concrete. NBS Building Materials and Structures Report BMS124 (1951).

[9] Fire grading of buildings, British Building Research Board, Post-War Building Study No. 20 (1946).

[10] Fire-resistance classifications of building construction, NBS Building Materials and Structures Report BMS92, Report of Subcommittee on FireResistance Classifications of the Central Housing Committee on Research, Design, and Construction (1942).

\section{ADDITIONAL REFERENCES}

Fire-resistance and sound insulation ratings for walls, partitions, and floors, NBS Technical Report on Building Materials 44 (1946).

H. P. Gurney and J. Lurie, Charts for estimating temperature distributions in heating and cooling solid shapes, Ind. and Fng. Chem. 15, 1170 (1923).

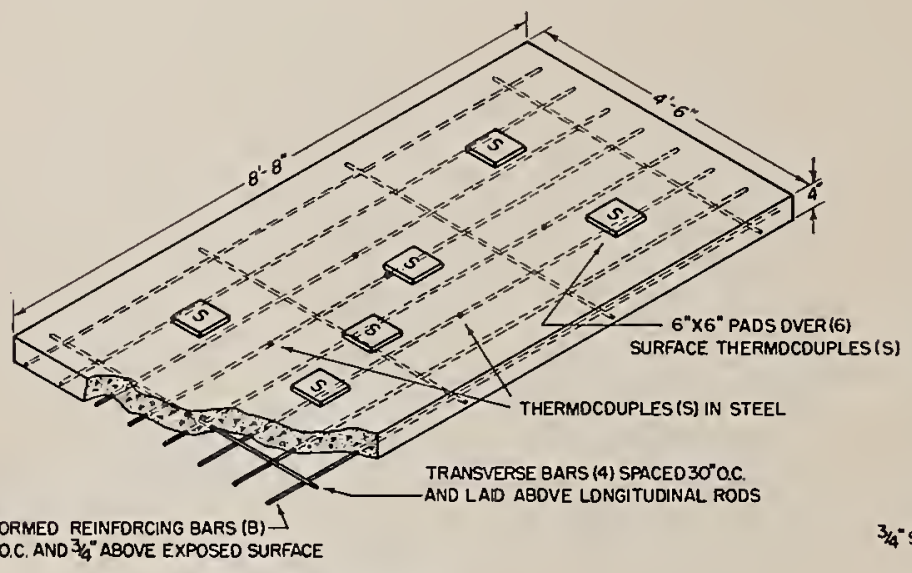

TEST NO. 25-A

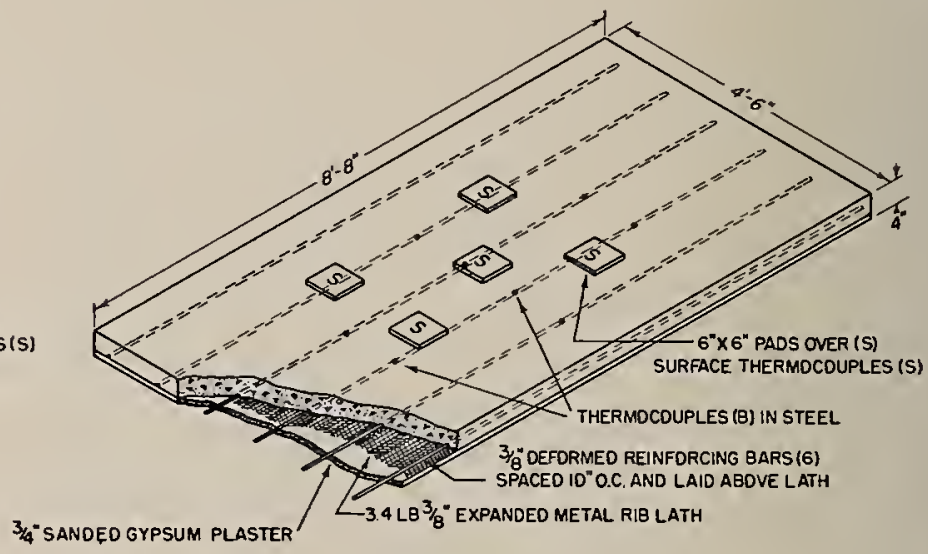

'TEST NO. 27 -A

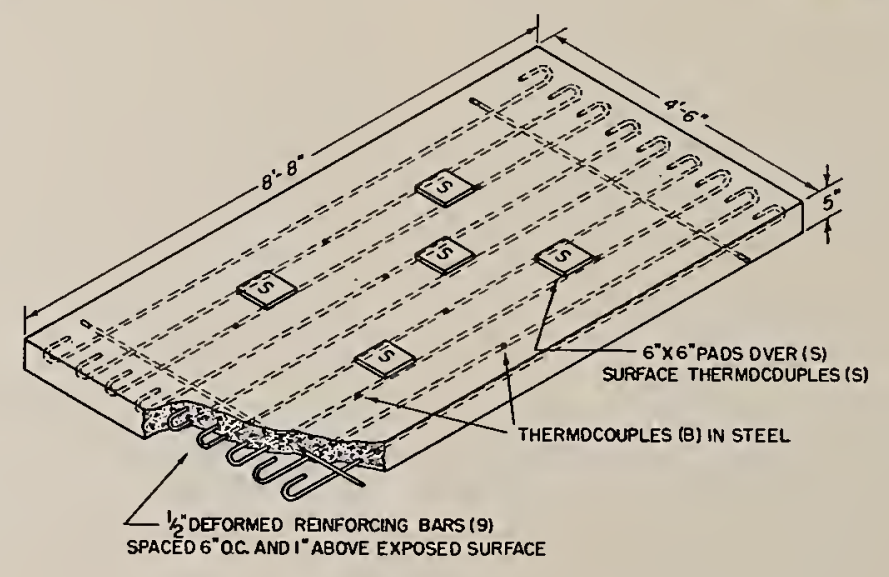

TEST NO 30-A

HIgURE 1. Construction of floors $25 \mathrm{~A}, 2 \gamma \mathrm{A}$, and $30 \mathrm{~A}$. 


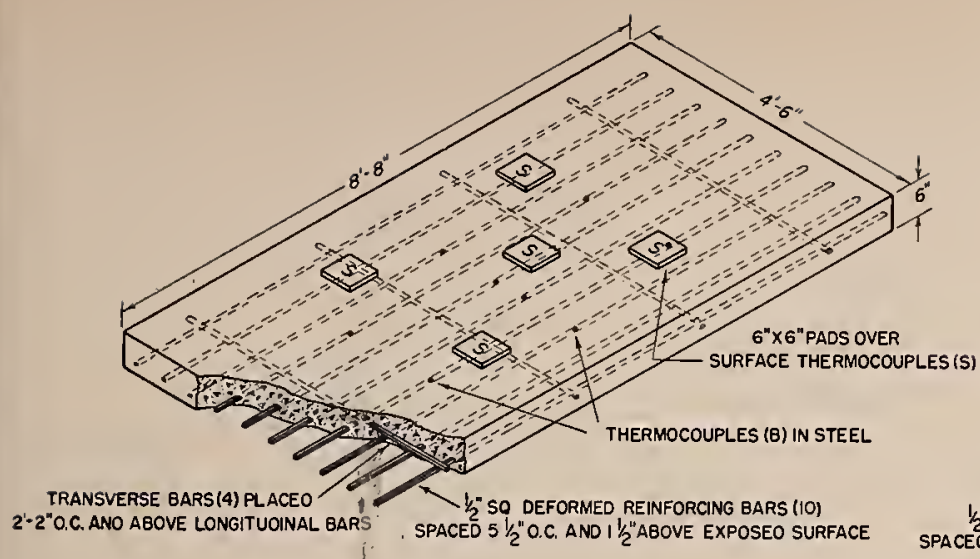

TRANSVERSE BARS(4) PLACEO
$2 \cdot 2^{\prime O}$ O.C. ANO ABOVE LONGITUOINAL BARS

IEST NO. 35-A

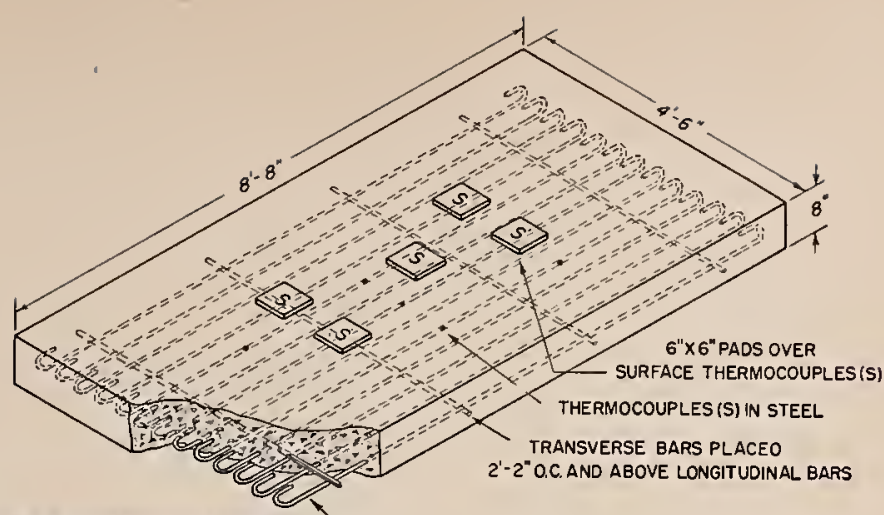

$1 / 2$ "SQ DEFORMED REINFORCING BARS (13) SPACEO 4"O.C. ANO : 12 "ABOVE EXPOSEO SURFACE $\longrightarrow$

TEST NO. 38-A

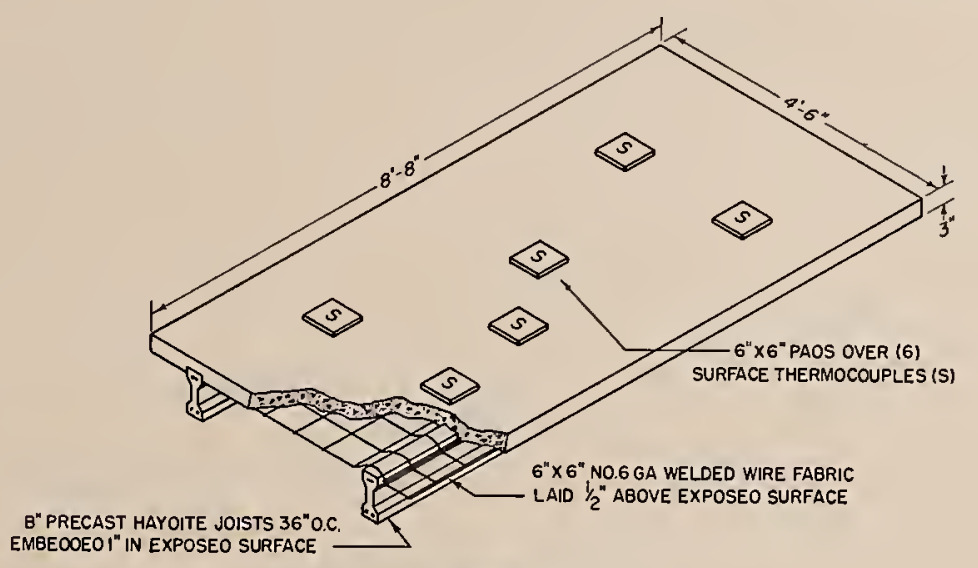

TEST NO.71-A AND RETEST NO.71-A

FigURE 2. Construction of floors $35 A, 38 A$, and $71 \mathrm{~A}$.

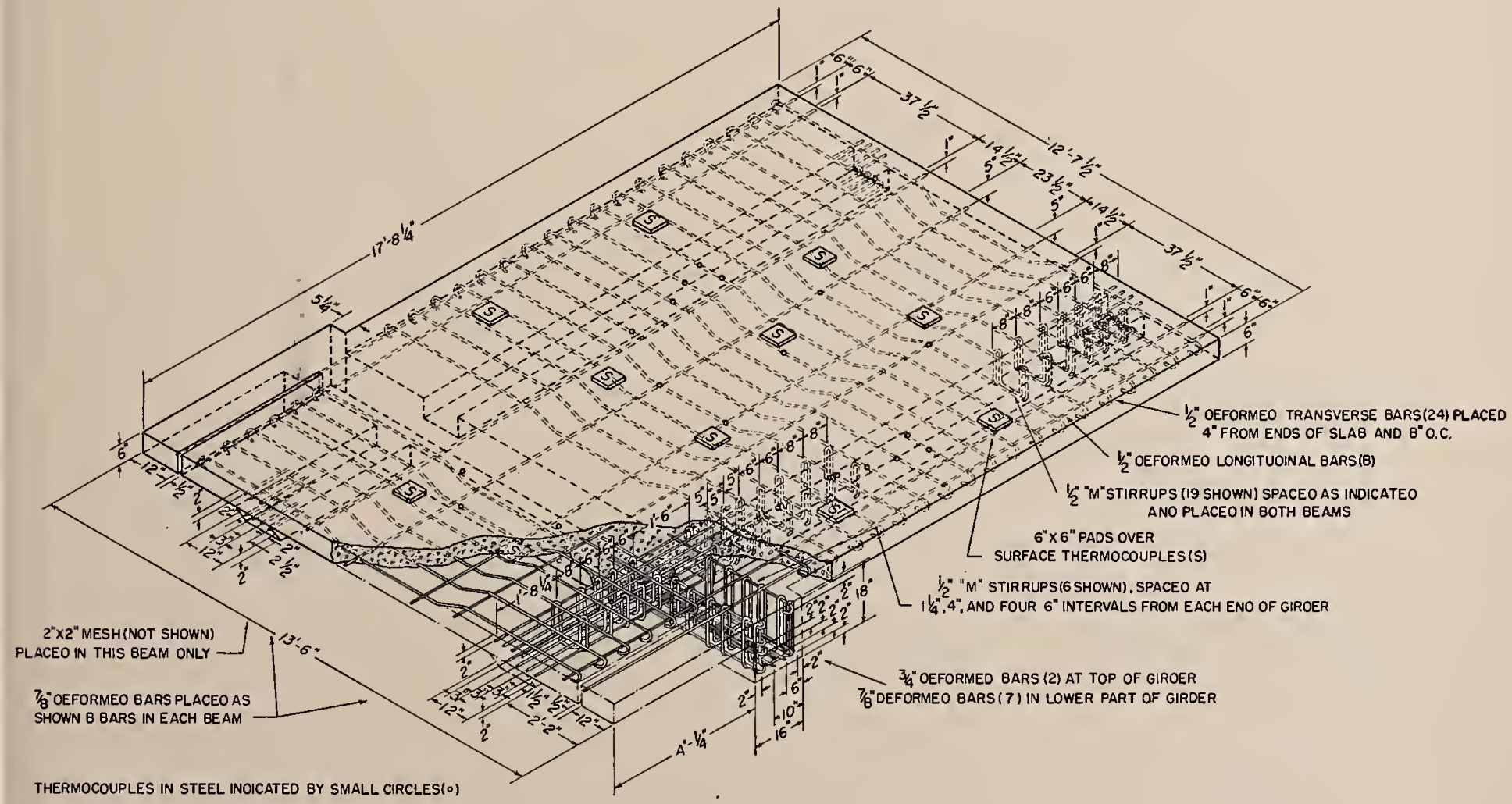

TEST NO. 37

Figure 3. Construction of floor 37. 


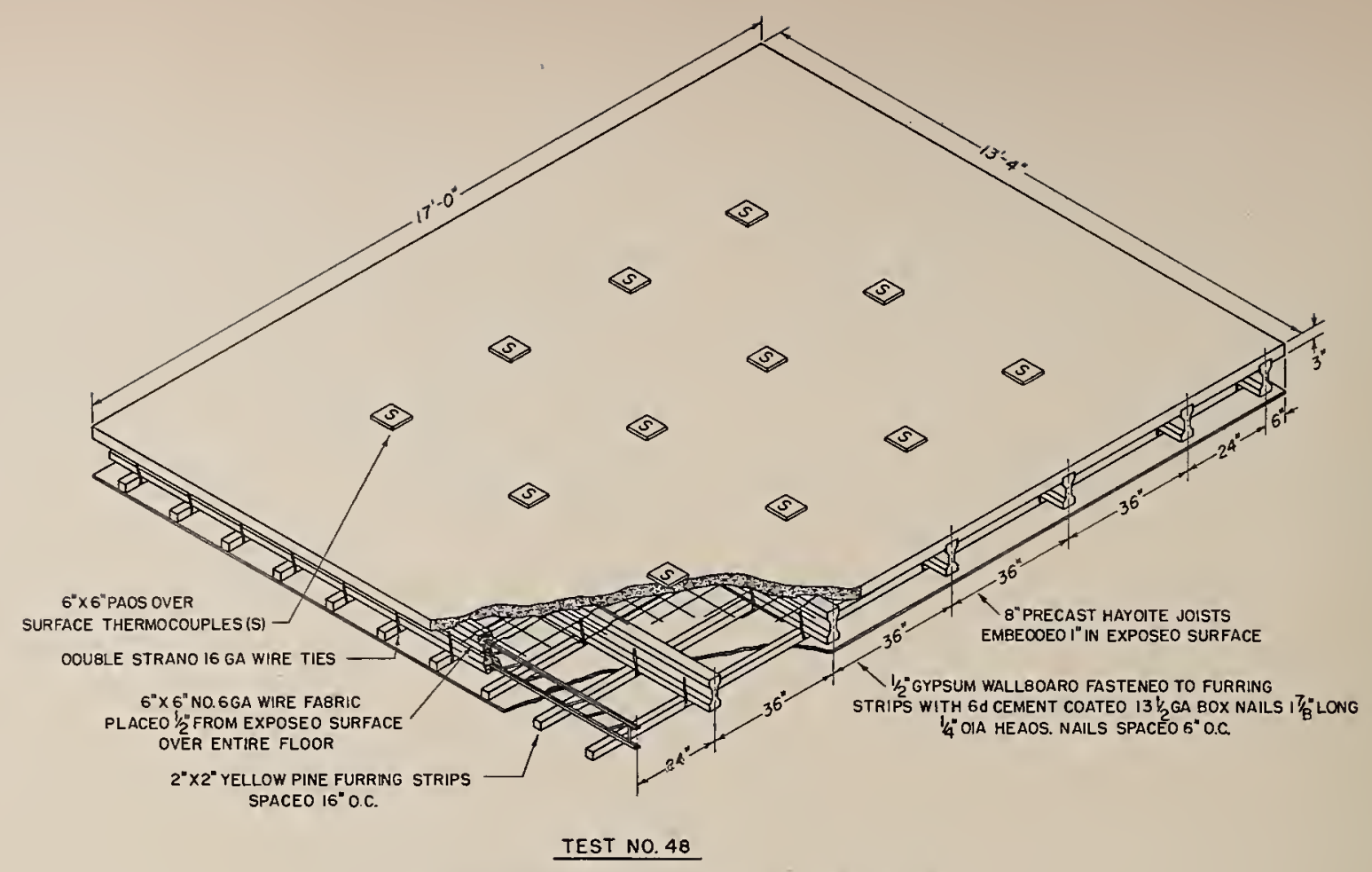

FrgURe 4. Construction of floor 48.

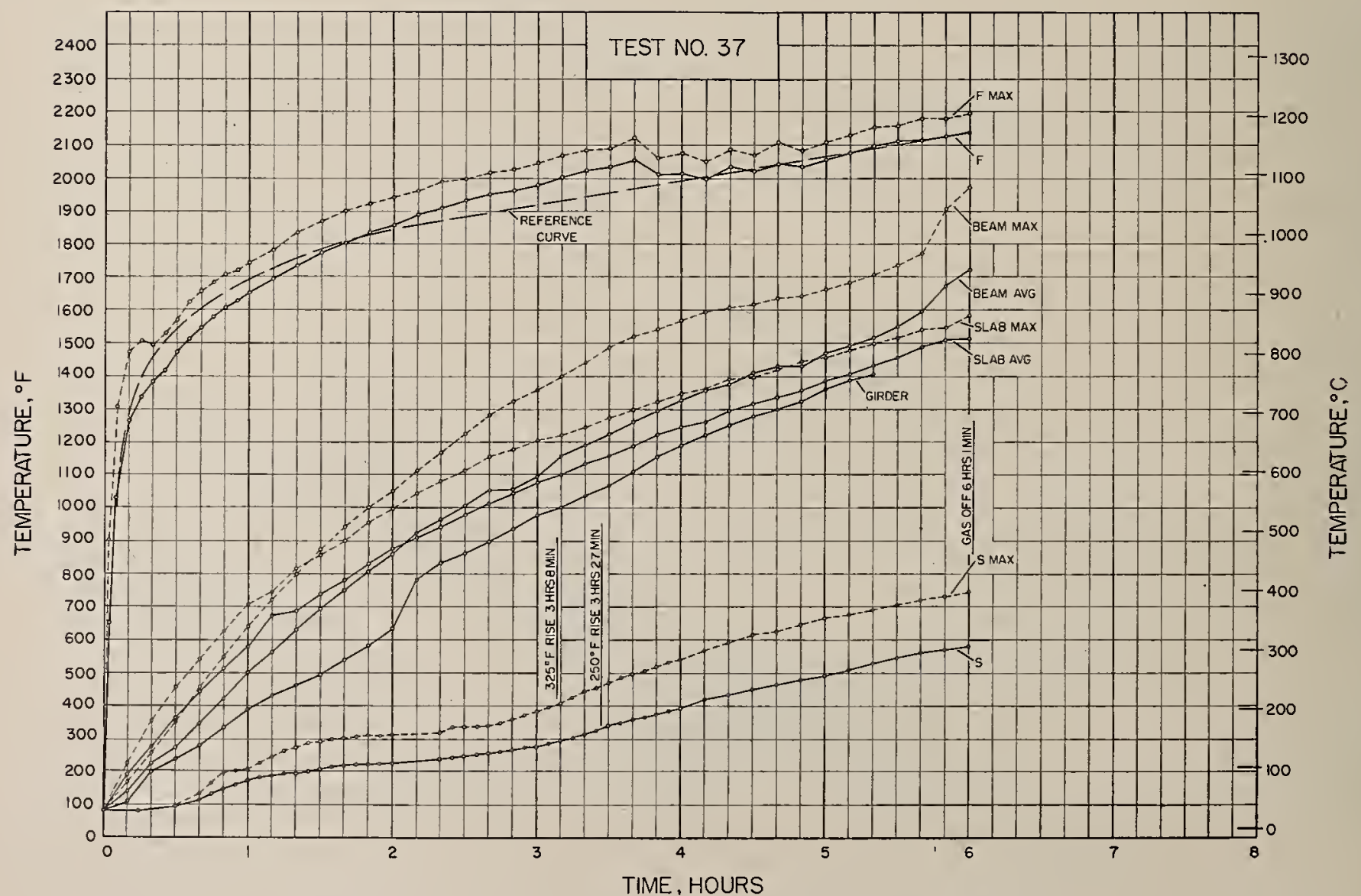

Figune 3. Surface, steel, and furnace temperatures for floor 37. 


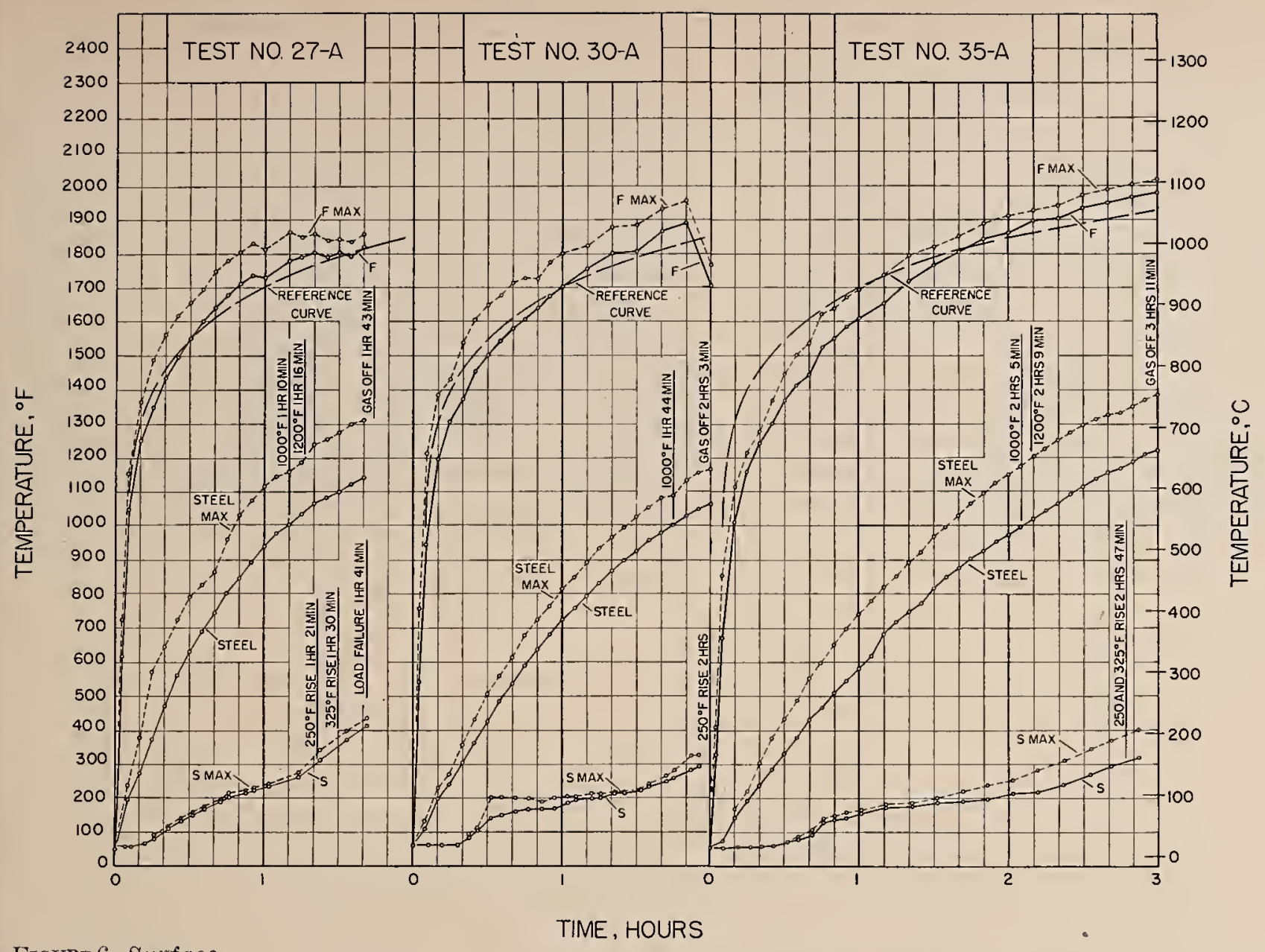

Figure 6. Surface,

steel, and fur-

nace tempera-

tures for floors

$2 \gamma \mathrm{A}, 30 \mathrm{~A}$, and

$35 \mathrm{~A}$.

Figure 7. Surface, steel, and furnace tcmperatures for floor $38 \mathrm{~A}$.

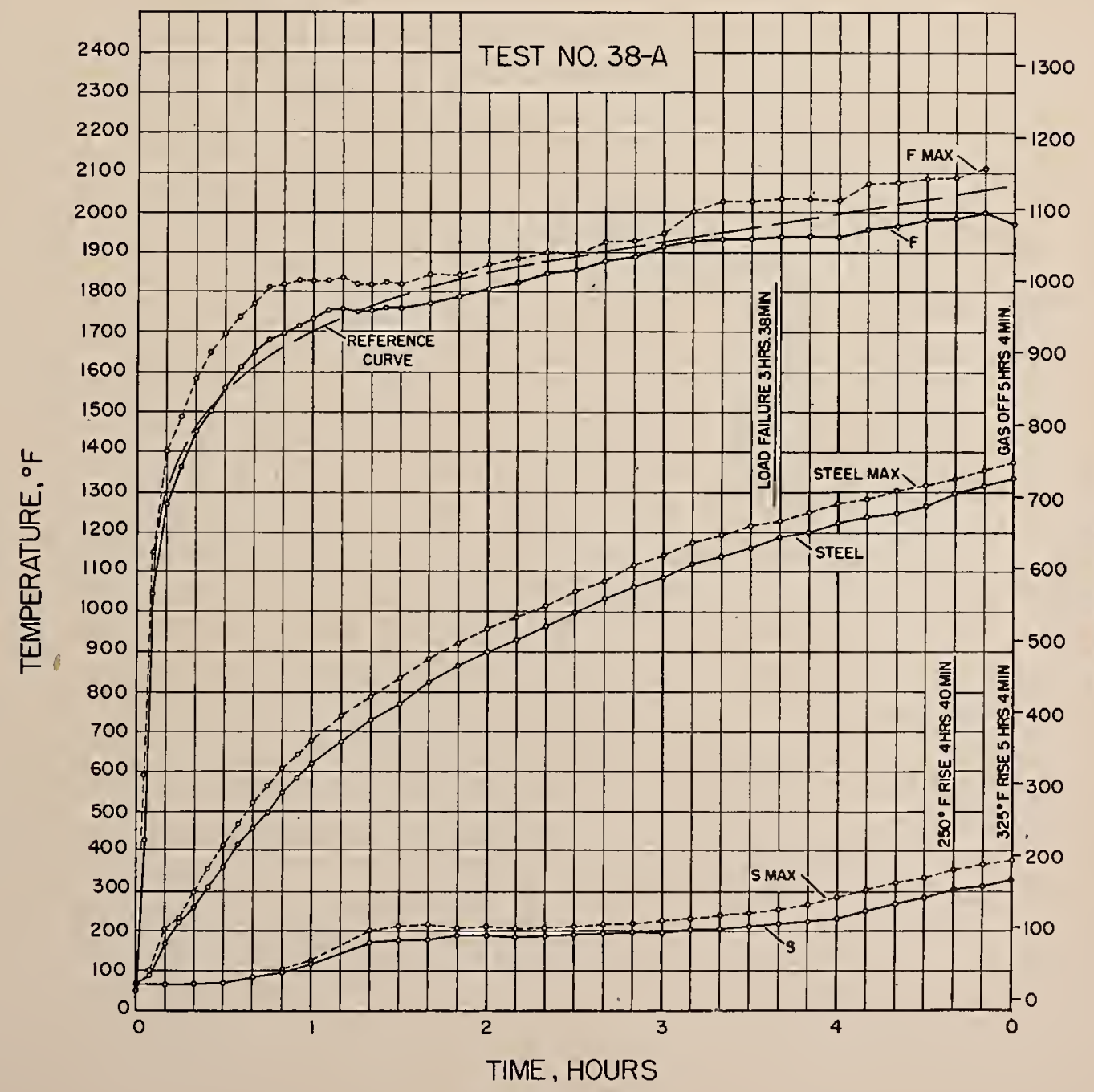




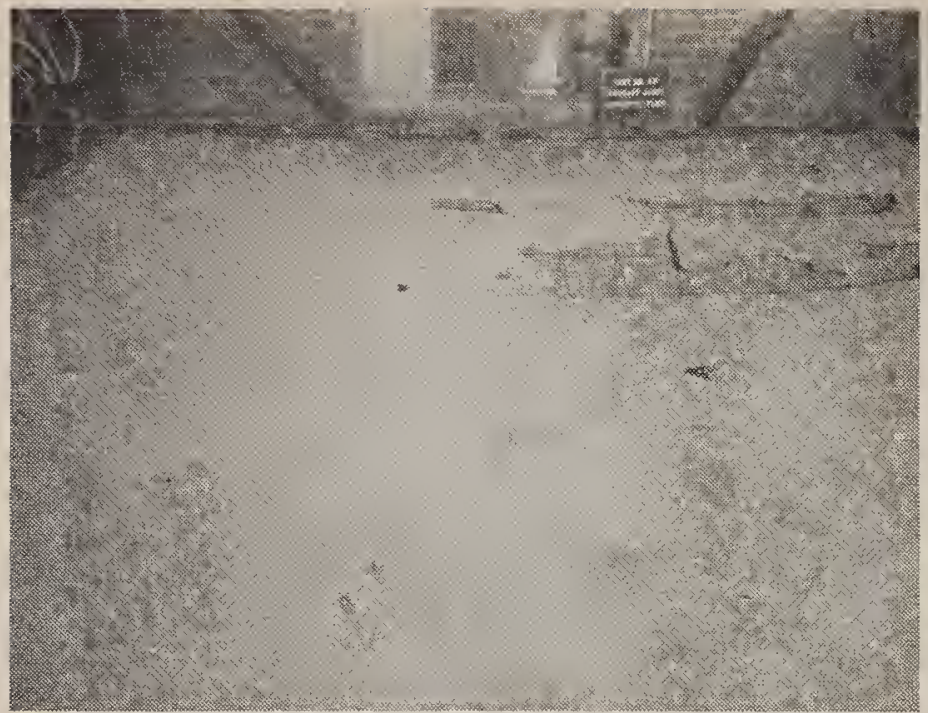

FIaURE S. Floor 47 after test showing holes in 21/2-in. slab formed by spalling.

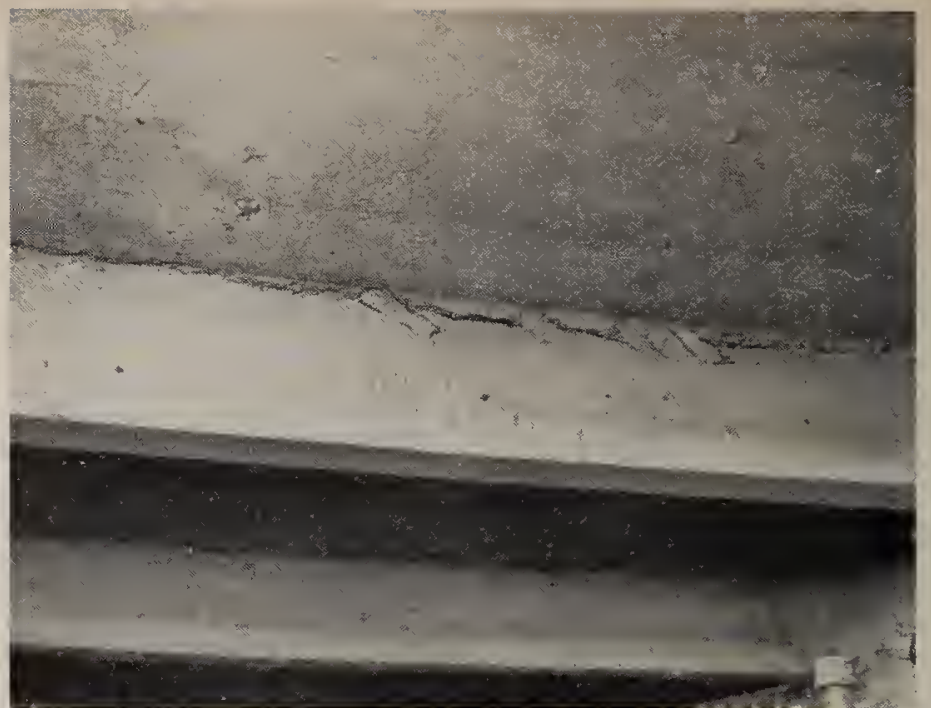

FIGURE 9. Detail showing shear failure between joist and 3 -in. slab of floor $4 \%$.

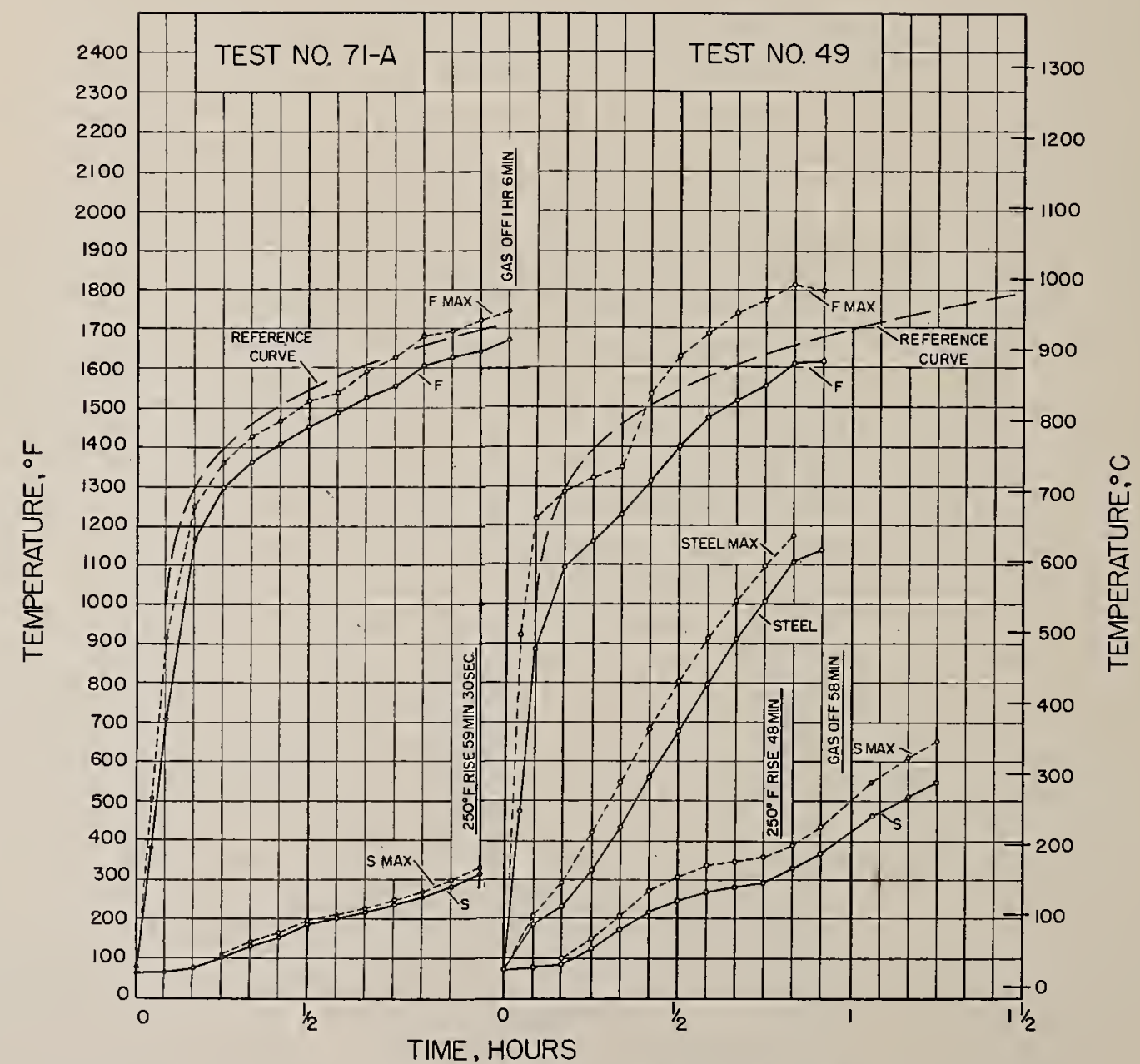

FIGURe 10. Surfaee, steel, and furnace temperatures for floors i1 and 49 . 


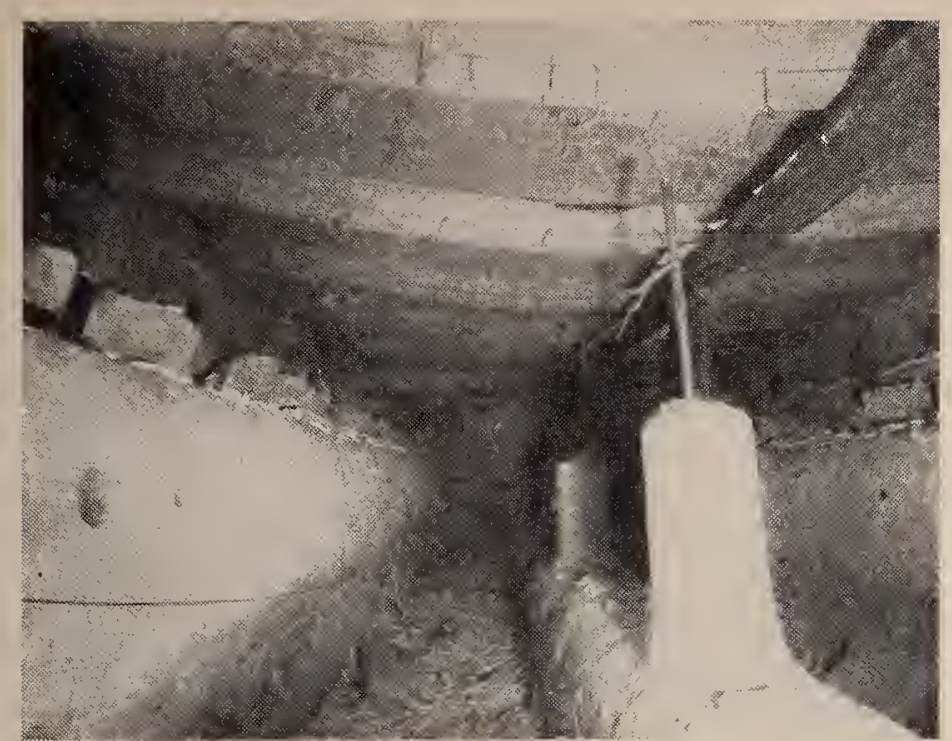

FrgURe 11. Exposed side of floor 48 after fire-enduranee test.

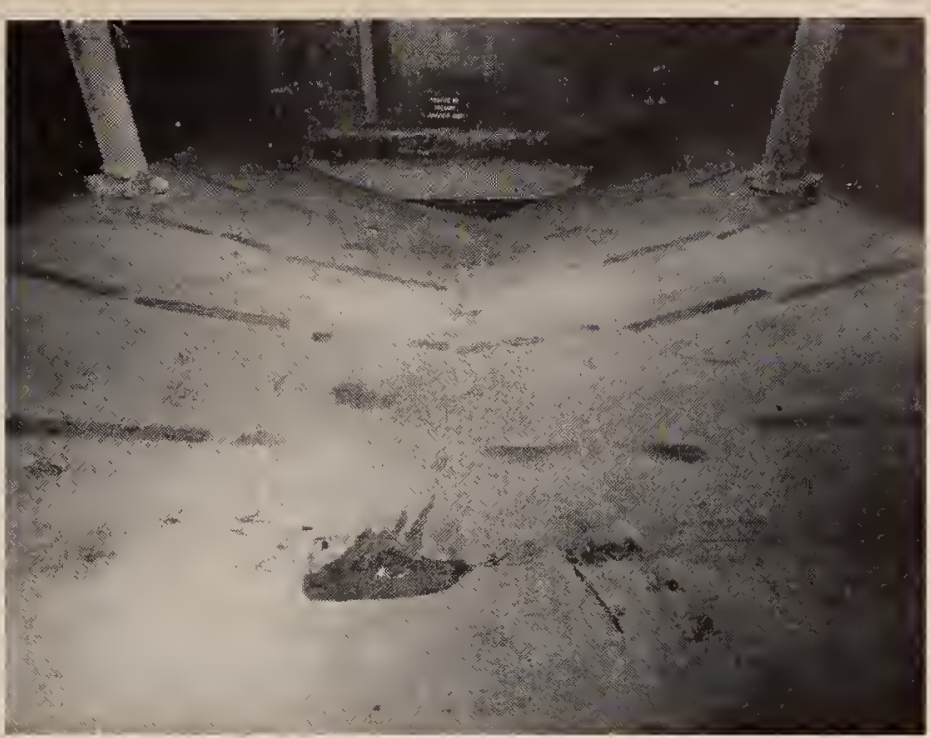

Figure 12. Unexposed surface of floor 49 after fireenduranee test.

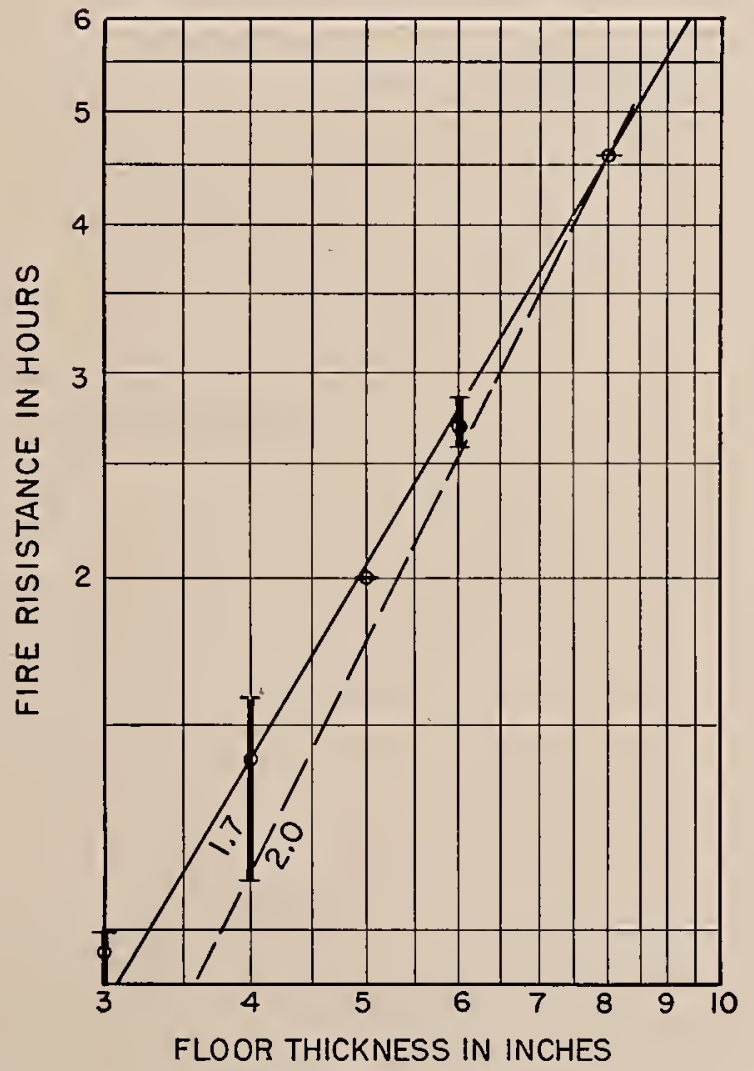

Figure 13. Fire resistanee, $t_{f}$, as a funetion of slab thickness, $L(\log -\log$ plot $)$.

Vertical lines show range of data; circles show average fire endurance for a given thickness. The solid line, 1.7 power, gives the best linear fit; the dashed line shows that a 2.0 power might also conceivably fit the data.

Wasmington, October 6, 1952. 





\title{
BUILDING MATERIALS AND STRUCTURES REPORTS
}

\author{
[Continued from cover page $\mathrm{rr}$ ]
}

BMS34

BMS36

BMS38

BMS39

BMS43

BMS44

BMS47

BMS48

BMS50

BMS51

BMS52

BMS53

BMS54

BMS55

BMS58

BMS60

BMS62

BMS63

BMS65

BMS66

BMS67

BMS68

BMS69

BMS70

BMS71

BMS72

BMS73

BMS74

BMS76

BMS77

MBS78

BMS79

BMS80

BMS81

BMS82

BMS83

BMS85

BMS86

BMS87

BMS89

BMS90

Performance Test of Floor Coverings for Use in Low-Cost Housing: Part 1

Structural Properties of Wood-Frame Wall, Partition, Floor, and Roof Constructions With "Red Stripe" Lath Sponsored by The Weston Paper and Manufac-

turing Co W. E. Dunn Manufacturing Co

Structural Properties of a Wall Construction of "Pfeifer Units" Sponsored by the Wisconsin Units Co

Performance Test of Floor Coverings for Use in Low-Cost Housing: Part $2 \ldots$

Surface Treatment of Steel Prior to Painting

Structural Properties of Prefabricated Wood-Frame Constructions for Walls, Partitions, and Floors Sponsored by American Houses, Inc

Structural Properties of "Precision-Built" Frame Wall and Partition Constructions Sponsored by the Homasote Co

Stability of Fiber Building Boards as Determined by Accelerated Aging ........... $10 \phi$

Structural Properties of "Tilecrete Type A" Floor Construction Sponsored by the Tilecrete $\mathrm{Co}$

Effect of Ceiling Insulation Upon Summer Comfort

Structural Properties of a Masonry Wall Construction of "Munlock Dry Wall Brick" Sponsored by the Munlock Engineering Co

Effect of Soot on the Rating of an Oil-Fired Heating Boiler

Effects of Wetting and Drying on the Permeability of Masonry Walls

Strength of Soft-Soldered Joints in Copper Tubing

Strength, Absorption, and Resistance to Laboratory Freezing and Thawing of Building Bricks Produced in the United States

Structural Properties of a Precast Joist Concrete Floor Construction Sponsored by the Portland Cement Association

Methods of Estimating Loads in Plumbing Systems

Plumbing Manual

Structural Properties of "Mu-Steel" Prefabricated Sheet-Steel Constructions for Walls, Partitions, Floors, and Roofs, Sponsored by Herman A. Mugler........-

Performance Test for Floor Coverings for Use in Low-Cost Housing: Part 3.-.-.- 20

Stability of Fiber Sheathing Boards as Determined by Accelerated Aging

Asphalt-Prepared Roll Roofings and Shingles

Fire Tests of Wood- and Metal-Framed Partitions__.

Structural Properties of "Precision-Built, Jr." Prefabricated Wood-Frame Wall Construction Sponsored by the Homasote $\mathrm{Co}$

Indentation Characteristics of Floor Coverings

Structural and Heat-Transfer Properties of "U. S. S. Panelbilt" Prefabricated SheetSteel Constructions for Walls, Partitions, and Roofs Sponsored by the Tennessee Coal, Iron \& Railroad Co .

Effect of Outdoor Exposure on the Water Permeability of Masonry Walls

Properties and Performance of Fiber Tile Boards

Structural, Heat-Transfer, and Water-Permeability Properties of Five Earth-Wall Constructions

Water-Distributing Systems for Buildings

Performance Test of Floor Coverings for Use in Low-Cost Housing: Part 4

Field Inspectors' Check List for Building Constructions (cloth cover, $5 \times 1 \frac{1}{2}$ inches)-

Water Permeability of Walls Built of Masonry Units

Strength of Sleeve Joints in Copper Tubing Made With Various Lead-Base Solders.-Temperature

Structural, Heat-Transfer, and Water-Permeability Properties of "Speedbrik" Wall Construction Sponsored by the General Shale Products Corporation....

A Method for Developing Specifications for Building Construction-Report of Subcommittee on Specifications of the Central Housing Committee on Research, Design, and Construction . - of Structural Properties of "Precision-Built, Jr." (Second Construction) Prefabricated Wood-Frame Wall Construction Sponsored by the Homasote Co Structural Properties of "PHC" Prefabricated Wood-Frame Constructions for Walls, Floors, and Roofs Sponsored by the PHC Housing Corporation.

[List continued on cover page Iv] 


\section{BUILDING MATERIALS AND STRUCTURES REPORTS}

\section{[Continued from cover page III]}

BMS92

BMS94

BMS95

BMS96

BMS99

BMS100

BMS101

BMS102

BMS103

BMS104

BMS105

BMS106

BMS108

BMS109

BMS110

BMS111

BMS112

BMS113

BMS114

BMS115

BMS116

BMS117

BMS118

BMS119

BMS120

BMS121

BMS122

BMS123

BMS124

BMS125

BMS126

BMS127

BMS128

BMS129

BMS130

BMS131

BMS132

BMS133

BMS134

Fire-Resistance Classifications of Building Constructions _............ $30 \phi$

Water Permeability and Weathering Resistance of Stucco-Faced, Gunite-Faced, and

"Knap Concrete-Unit" Walls

Tests of Cement-Water Paints and Other Waterproofings for Unit-Masonry Walls
Properties of a Porous Concrete of Cement and Uniform-Sized Gravel

Structural and Heat-Transfer Properties of "Multiple Box-Girder Plywood Panels" for

Walls, Floors, and Roofs.

Relative Slipperiness of Floor and Deck Surfaces.

Strative Shes

Strength and Resistance to Corrosion of Ties for Cavity Walls

Painting Steel_...

Measurements of Heat Losses From Slab Floors

Structural Properties of Prefabricated Plywood Lightweight Constructions for Walls,

Partitions, Floors, and Roofs, Sponsored by the Douglas Fir Plywood Association - $30 \notin$

Paint Manual With Particular Reference to Federal Specifications _ _ _ _ _._. _ _ _ $\$ 1.25$

Laboratory Observations of Condensation in Wall Specimens

Temperature Distribution in a Test Bungalow With Various Heating Devices...

Strength of Houses: Application of Engineering Principles to Structural Design

Paints for Exterior Masonry Walls

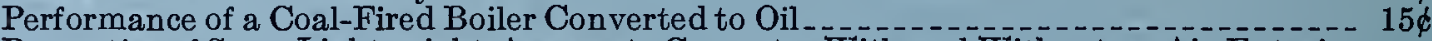

Properties of Some Lightweight-Aggregate Concretes With and Without an Air-Entrain-

ing Admixture - . - -

Pesistance of Structural Clay Tile Partitions

Temperature in a Test Bungalow With Some Radiant and Jacketed Space Heaters

A Study of a Baseboard Convector Heating System in a Test Bungalow

Preparation and Revision of Building Codes

Fire Resistance of Walls of Lightweight Aggregate Concrete Masonry Units

Stack Venting of Plumbing Fixtures

Wet Venting of Plumbing Fixtures

Fire Resistance of Walls of Gravel-Aggregate Concrete Masonry Units.

Investigation of Failures of White-Coat Plasters

Physical Properties of Some Samples of Asbestos-Cement Siding

Fire-Tests of Wood-Framed Walls and Partitions With Asbestos-Cement Facings_..-_- $15 \phi$

Fire Tests of Steel Columns Protected With Siliceous Aggregate Concrete

Stone Exposure Test Wall_.......-_-

The Self-Siphonage of Fixture Traps.

Effect of Aging on the Soundness of Regularly Hydrated Dolomitic Lime Putties.-.. 15

Atmospheric Exposure Tests of Nailed Sheet Metal Building Materials_._-_-_-_-_-_ 20

Fire Endurance of Shutters for Moving-Stairway Openings

Methods and Equipment for Testing Printed-Enamel Felt-Base Floor Covering

Fire Tests of Gunite Slabs and Partitions...

Capacities of Plumbing Stacks in Buildings.

Live Loads on Floors in Buildings . .

Fire Resistance of Concrete Floors 






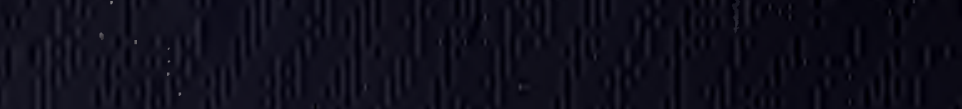

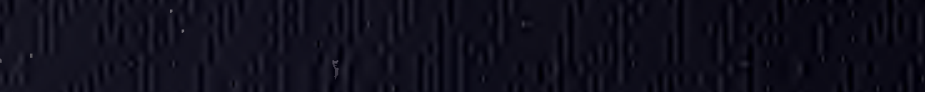

ii

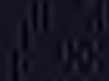

|inting

(i)

(1)

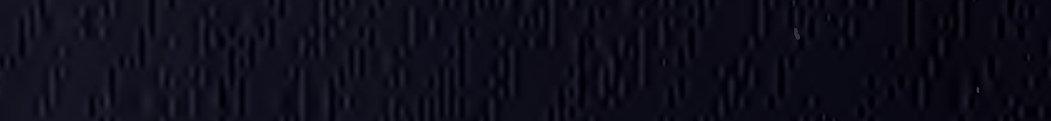

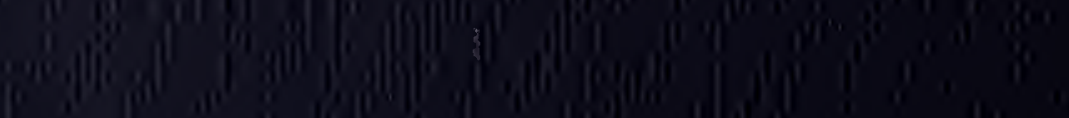

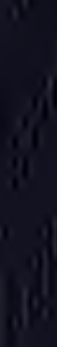

1

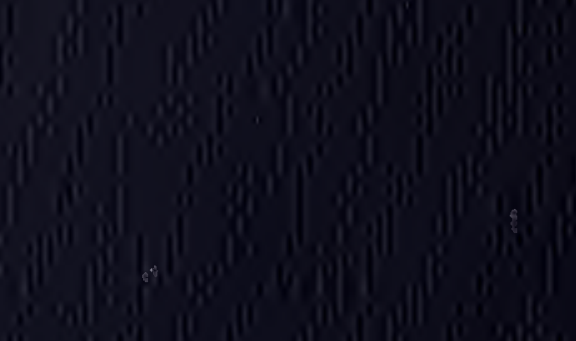

(1)

年,

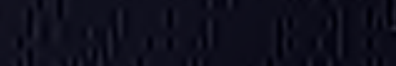

(1).110

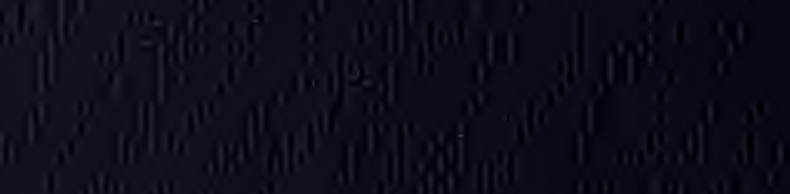

|

6.

|l 